\title{
Energy Policy of the State as a Key Factor in Modern Foreign Affairs
}

\author{
Oleg Grishin ${ }^{1}{ }^{*}$ Ralitsa Todorova ${ }^{1}$, Laith Mahdi ${ }^{1}$, Marats Kasems ${ }^{1}$ \\ ${ }^{I}$ Peoples' Friendship University of Russia (RUDN University), Russia \\ "Email: grishin_oe@pfur.ru
}

\begin{abstract}
The article aims to analyze the role of energy policy in the development of modern states in the context of foreign affairs. Energy security is an essential element here. Attention is focused on the fact that the problem of energy security often remains uncertain, misunderstood or incomprehensible; countries remain almost blind hostages of threats with dangerous consequences. The growing dependence of the majority of developed industrial countries on oil and gas supplies and the growing demand for fuel from developing countries are shown.

Using the example of the European Union, the article demonstrates energy dependence on energy supplies from supplying countries, emphasizes the interconnectedness of energy markets and routes, identifies vectors for the development of its energy policy, and outlines potential ways to solve the problems of energy dependence.

This paper has been supported by the RUDN University Strategic Academic Leadership Program.
\end{abstract}

Keywords: Energy policy, State, Energy security, Energy independence, Foreign affairs.

\section{INTRODUCTION}

A state with ambitions and potential for an active foreign policy in the modern world must have a strategic energy policy and sufficiently developed energy systems [1]. Energy resources are needed to stimulate economic growth and improve the standard of living of its citizens. The growing dependence on imports of energy resources is increasing in parallel with population growth and development of countries [2]. The energy sector is developing more and more dynamically and requires adequate and timely political decisions. Energy policy must respond to changing conditions and adapt to them per existing international relations [3]. Currently, there is a need to accumulate specialized knowledge in the energy field among political scientists, as well as to provide a platform for the exchange of experience and free dialogue between individual countries [4]. In this sense, this analysis is an attempt to address some of the critical issues associated with current energy policy. The energy policy of the state today is one of the priorities of the political agenda.

\section{RESEARCH METHODOLOGY}

The research is based on the work of researchers analyzing energy policy, the peculiarities of political and state management of energy processes and risks in the context of political, economic and systemic approaches. The methodological basis of the research consists in the use of a systemic, institutional, structural and functional approach. The use of these approaches made it possible to solve the assigned tasks. The study used historical and comparative methods, methods of analysis and synthesis, and observation.

\section{STUDY RESULTS}

Singling out energy policy as a separate sphere of public administration, let us turn to the definition of S.S. Lachininsky [5], who defined energy policy as a joint activity of the state and business, focused on achieving economic goals. M.B. Petrov [6] and S.V. Tanaylov [7] also believe that the state and public authorities are the main actors in energy policy. We agree with the opinions of these researchers. States continue to be essential players in foreign affairs. 
An essential component in building energy relations between individual states is "energy nationalism". This is evident in the negotiations on the construction of the Trans-Caspian gas pipeline for gas supplies to Europe, which will supply gas from Central Asia to the European Union (EU). The EU must find and invest funds directly from itself or through the European Investment Bank in the construction of the Trans-Caspian gas pipeline. These investments should be no less than those of Azerbaijan (in the construction of the Trans-Anatolian gas pipeline) and Turkmenistan (in the construction of a gas pipeline from the eastern regions of the country to the Caspian Sea) [8]. In turn, Turkmenistan must agree on the joint exploitation of fields on its territory with leading European companies or consortia to attract investments in the production and transportation of natural gas [9].

Energy independence issues create some vulnerability in the interdependence between Russia and the EU. The last one is a significant partner of Russia in the energy sector. This fact is evidenced by the implemented energy projects of Russia and the EU, such as:

- Baltic pipeline system (500 billion tons of oil per year, 2018) [10];

- Yamal-Europe gas pipeline (33 billion cubic meters of gas per year, 2019) [11];

- Nord Stream gas pipeline (55 billion cubic meters of gas per year, 2019) [12].

The analysis showed that the Russian Federation is currently both a major gas supplier and a major consumer. If the European market stops supplying from Russia and switches to another supplier, or vice versa, if Russia stops supplies to the EU, this will lead to significant changes in energy relations between the countries involved. Dialogue between interested countries, minimizing inequality and finding a balance of interests between supplying and consuming countries is essential.

In the modern world energy arena, the place occupied by Turkey in energy relations between Russia and the EU is of particular interest. For Russia, Turkey is not only a critical transit route for energy carriers but also an alternative consumer in the framework of Moscow's efforts to reduce dependence on supplies to European markets [13]. After Ukraine and Germany, Turkey is the third-largest importer of Russian gas, and Turkey's NATO membership is not an obstacle to the country's energy partnership with Russia. Turkey also wants to contribute to the development of European energy policy and build the Southern Gas Corridor through which oil and gas from the Caspian region and the Middle East can reach Europe. The development of Turkey-Russia and Turkey-EU bilateral relations further enhances this potential project in terms of its geopolitical significance in the region.
Non-EU countries generally follow a union approach to shifting regulatory boundaries (extending EU rules, regulations and institutions beyond its borders). The trend towards the development of renewable energy sources is also part of the energy policies of the respective countries aimed at facilitating their future integration into the EU. For example, the electricity market in Southeast Europe is relatively small and consists of separate national markets, which stimulates regional efforts to attract infrastructure investors. The region can take advantage of its strategic geographic location and Southern Corridor negotiations to positively stimulate investment. The analysis showed that issues affecting the entire region include the lack of significant progress in the elimination of regulated energy prices, the prevention of electricity losses at the consumer level, and a lack of understanding of the importance of electricity.

The creation of a competitive internal energy market is one of the critical steps taken by the EU to pursue "smart" energy policies. It is a strategic tool both for European consumers, who will be able to choose between different companies supplying natural gas and electricity at affordable prices and for a market that will be available to all suppliers, including those who invest in renewable energy. There is also the challenge of creating a legal framework in which carbon trading mechanisms can function correctly. The creation of such an internal energy market depends primarily on the availability of a reliable and consistent energy network in Europe and on investment in infrastructure. A truly integrated market would facilitate diversification and, therefore, the security of supply.

We state that the dynamics of economic development in Europe in the second half of the 20th century gradually formed an understanding of the need for a common EU energy market, and the changed risks at the beginning of the 21 st century require a special policy to protect the most critical energy infrastructures in Europe. With the opening of European energy markets to competition fifteen years ago, European citizens and industry are reaping many benefits: more choice, increased competition for lower prices, better services and greater security of supply. Since July 2004, small business customers in all EU countries can freely change their gas and electricity suppliers, and since July 2007 all consumers have received the same opportunity. In each EU Member State, an independent national regulatory body has been established to ensure that the suppliers and companies in the network operate correctly and deliver the services promised to their customers. Since 2003, the heads of national energy regulators have been consolidated into the European Electricity and Gas Regulators Group, which acts as an advisory body to help the European Commission consolidate the internal electricity and gas market. 
The EU faces severe dependence on all types of imported fossil fuels (coal, natural gas, oil). Domestic production of fossil fuels is declining across the EU due to limited reserves, environmental concerns or trade considerations. The EU's strategy places great emphasis on the security of supply and is linked to the proper functioning of the single market, as well as the promotion of renewable energy sources and energy efficiency schemes that increase energy security by reducing dependence on imported fossil fuels. Ensuring the security of supply requires continuous efforts on the part of the EU and its member states. It includes careful monitoring of the reliability of third-country suppliers and an assessment of how new supply routes (or the closure of old ones) could affect energy security. It is essential to ensure that agreements with third countries are in line with EU objectives and that the choice of energy supplier at the national level does not negatively impact the security of supply at the regional level.

\section{RESULTS DISCUSSION}

Priorities, challenges and trends in global and European energy and climate policy are the fight against negative climate change; improving energy efficiency; reducing the EU's external dependence on imported energy resources and promoting economic growth by providing safe and affordable energy to consumers in member countries. The development of the internal energy market is required to solve such problems. Diversification of sources and supply routes of natural gas is essential both for national security and for the energy independence of countries.

Building the necessary infrastructure and diversifying energy supplies are key to ensuring energy security. European grids require considerable investments to replace ageing infrastructure and adapt to low-carbon and renewable energy sources. A strategic initiative to ensure the EU's energy security is the development of the Southern Gas Corridor for the supply of natural gas from sources in the Caspian Sea region and the Middle East [14].

The energy transition is currently underway, which is defined as "accelerated technological progress in several industries, which is contributing to unprecedented rates of public desire for system sustainability". The goal is an "epoch-making change" in the way the world's people consume energy and natural resources. The following events are expected: the emphasis in energy policy is on decarbonization; energy efficiency is penetrating "all markets"; nuclear energy, despite the absence of greenhouse gas emissions, is not unequivocally acceptable due to "negative public attitudes and disproportionate cost increases"; hydrogen is central to the energy system; stricter restrictions on the one-time use of plastic products (raw materials for which are hydrocarbons); technologies for direct capture/absorption of hydrocarbons from air and agricultural soils; in the case of electric vehicles, parity is achieved with the prices of vehicles with combustion engines earlier than expected; the cost of renewable energy sources, as well as long-term storage of energy, which are interconnected, are falling sharply. The electrification of an increasing number of processes and systems is gaining momentum (mainly due to renewable energy sources), so digitalization, another revolutionary factor, is becoming a key solution for balancing energy systems at the national and international levels [15].

Thus, today about $80 \%$ of the world's population lives in countries that are net importers of hydrocarbon fuels. Renewable sources allow them to achieve energy security without energy imports. Renewable energies and technologies are decentralizing and democratizing national energy systems and transforming individual households and consumer communities into a transition to energy and climate management. By 2050, about $70 \%$ of the world's population will live in cities, where the impact of the energy transition will be strongest. Metropolitan areas and civil society will determine the trends in energy and climate policy in the world.

\section{CONCLUSIONS}

The development of energy markets is significant for the future development of the European Union's energy policy. EU policy aims to instigate a new industrial revolution that will lead to the construction of a lowenergy economy with more reliable, competitive and sustainable energy consumption.

A reliable power supply is essential for the well-being of citizens and the proper functioning of businesses and social services. To a large extent, each EU member state is free to determine its energy supply structure.

The security of supply is guaranteed primarily by the national authorities. However, the interconnectedness of energy markets and their supply routes requires close coordination between neighbour countries to ensure the security of supply. The EU national energy markets are more interconnected than in the past and operate within a common legal framework.

The energy transition is accompanied by an exacerbation of the struggle of opposing strategic interests, which is likely to intensify. A growing number of energy, industrial, transportation, construction companies and financial institutions are stepping up their efforts to transition to market energy.

Technocratic solutions must be concretized and serve the direct interests of European citizens. The main task for European political institutions is to mobilize; otherwise, polarization will occur in the societies of European countries. Energy policy in the Member States 
and the EU as a whole faces fundamental practical problems and requires further study.

\section{REFERENCES}

[1] Advancing Energy Policy, Ch. Foulds, R. Robison (Eds.), Palgrave Pivot, 2018, 193 p. DOI: https://doi.org/10.1007/978-3-319-99097-2

[2] Energy Policy Making in the EU. J. Tosun, S. Biesenbender, K. Schulze (Eds.), Springer-Verlag London, 2015, 263 p. DOI: https://doi.org/10.1007/978-1-4471-6645-0

[3] Global Energy Policy and Security. W. Leal Filho, V. Voudouris (Eds.), Springer-Verlag London, 2013, 330 p. DOI: https://doi.org/10.1007/978-14471-5286-6

[4] M.G. Anokhin, O.E. Grishin, Energy Safety: Politics and Diplomacy, Przeglad Strategiczny 1 (2013) 155-164.

[5] S.S. Lachininsky, Some Issues of Implementation of Russia's Energy Policy in the Baltic Region: Geoeconomic Approach, Baltic Region 2(16) 2013 17.

[6] M.B. Petrov, Energy Policy of Russia: Realities and Opportunities, Bulletin of the Ural State Transport University 3(27) (2015) 52-63.

[7] S.V. Tanaylov, Energy Policy of Russia as a Factor of Ensuring National Security, Abstract of a dissertation for the degree of candidate of political sciences, Moscow, 2011. Retrieved from: http://reftrend.ru/428423.html

[8] I.A. Guliev, E.T. Mekhdiev, Azerbaijan in the system of international transport corridors, Eurasian Law Journal 1(104) (2017) 59-61.

[9] E.T. Mekhdiev, Euro-Asian transport corridors and the EEU, International Analytics 24 (2018) 47-56.

[10] The Baltic Pipeline System, 2019. Retrieved from: https://www.transneft.ru/about/developmentsystem/396/

[11] Yamal - Europe gas pipeline: Russian gas supplies to Western Europe, 2019. Retrieved from: https://www.gazprom.ru/projects/yamal-europe

[12] The Nord Stream gas pipeline, 2019. Retrieved from: https://www.gazprom.ru/projects/nordstream/

[13] Russia and Turkey are continually working to build up bilateral cooperation, 2019. Retrieved from: https://www.eprussia.ru/news/base/2019/8654633. $\underline{\mathrm{htm}}$
[14] S.I. Chernyavsky, E.T. Mekhdiev, Southern Gas Corridor in EU Energy Policy, Political Science Issues 4(32) (2018) 139-145.

[15] The Energy Union: from vision to reality, 2019. Retrieved

from: https://ec.europa.eu/commission/presscorner/detail/ bg/IP $19 \quad 1876$ 